\title{
ISOLASI BAKTERI DARI TANAH MANGROVE Rhizopora sp. DI KOTA BONTANG
}

\author{
Ayu Kusumah Dewi*, Lisna Meylina, Rolan Rusli \\ Laboratorium Penelitian dan Pengembangan FARMAKA TROPIS Fakultas \\ Farmasi Universitas Mulawarman, Samarinda, Kalimantan Timur \\ *Email:ayu.kusumahdewi106@gmail.com
}

\begin{abstract}
ABSTRAK
Kota Bontang merupakan salah satu kawasan mangrove terbesar di Kalimantan Timur. Hutan mangrove kaya akan bahan organik dan merupakan habitat yang mendukung pertumbuhan bakteri. Keragaman bakteri yang terdapat pada hutan mangrove saat ini masih belum dilaporkan sehingga tujuan dari penelitian ini adalah mengisolasi bakteri yang terdapat pada tanah kawasan hutan mangrove. Isolasi dilakukan menggunakan teknik streak (gores) dengan deret pengenceran $10^{-1}-10^{-5}$ pada media Nutrient Agar Fluconazole dilanjutkan dengan karakterisasi mengunakan pengamatan makroskopik, mikroskopik dan uji biokimia. Hasil penelitian ini diperoleh 14 isolat dimana telah dilakukan pemurnian terhadap 6 isolat dengan kode $\mathrm{K} 1, \mathrm{~K} 2, \mathrm{~K} 3, \mathrm{~K} 4, \mathrm{~K} 5$ dan $\mathrm{K} 6$. Hasil karakterisasi pada isolat $\mathrm{K} 1$ berbentuk basil gram negatif, $\mathrm{K} 2$ berbentuk basil gram negatif, $\mathrm{K} 3$ berbentuk spiral gram negatif, K4 berbentuk basil gram negatif, K5 berbentuk streptococcus gram positif dan K6 berbentuk coccus gram positif.
\end{abstract}

Kata Kunci: Isolasi, Karakterisasi, Mangrove, Bakteri Tanah, Bontang

\begin{abstract}
Bontang is one of the largest mangrove area in East Kalimantan. Mangrove forests are rich in organic matter and supports the growth of bacteria. The diversity of bacteria found in mangrove forests is not yet reported. The purpose of this study was to isolate the bacteria in the land area of mangrove forests. Isolation was done by using a streak technique (scratch) with a dilution series of $10^{-1}-10^{-5}$ on Nutrient Agar Fluconazole, followed by observation using macroscopic, microscopic and biochemical tests. The results of this study was obtained 14 isolates. 6 isolates has done purification, with code K1,K2, K3, K4, K5 and K6. 4 isolates (K1, K2, K3, $K 4)$ were negative gram bacteria and 2 isolates (K5 and K6) were positive gram. The shapes of isolates $K 1, K 2, K 3, K 4, K 5$, and $K 6$, were respectively bacilli, bacilli, spiral, bacilli, streptococcus, and coccus.
\end{abstract}

Keywords: Isolation, Characterization, Mangrove, Soil Bacteria, Bontang

Proceeding of the $5^{\text {th }}$ Mulawarman Pharmaceuticals Conferences, 


\section{PENDAHULUAN}

Ekosistem pesisir merupakan lingkungan yang menyediakan sumber daya alam yang sebagian besar belum termanfaatkan. Salah satu potensi dari bagian ekositem pesisir adalah kawasan mangrove. Hutan mangrove adalah tipe hutan yang khas dan terdapat di pantai tempat pertemuan muara daratan dan lautan. Daerah tersebut selalu dipengaruhi oleh pasang surut air laut. Lingkungan demikian terdapat ekosistem yang khas dan merupakan salah satu sumber daya alam yang sangat potensial karena di kawasan hutan mangrove terpadu unsur fisik, biologis daratan dan lautan. Kota Bontang merupakan salah satu kawasan mangrove terbesar di Kalimantan Timur yang terdiri berbagai jenis spesies mangrove (Fatiqin, 2015).

Keberadaan mikroorganisme pada ekosistem mangrove erat kaitannya dengan kestabilan ekosistem. Mikroorganisme berperan dalam siklus biogeokimia, serta terjadi simbiosis mutualisme antara bakteri dan tumbuhan. Sedimen laut termasuk juga kawsan mangrove berpotensi sebagai habitat mikroba khususnya aktinomycetes yang mempunyai aktivitas untuk menghasilkan senyawa-senyawa yang berguna (Katili, 2009).

Rhizophora sp. Merupakan salah satu jenis tanaman mangrove, yaitu kelompok tanaman tropis yang bersifat halopatik atau toleran terhadap garam. Rhizophora sp. memiliki ciri khas tersendiri untuk setiap daerah dan telah beradaptasi dengan lingkungan tumbuhnya sehingga berpengaruh pada keberadaan mikroorganisme. Mikroba yang bersimbiosis dengan tanaman seringkali spesifik untuk lokasi dan jenis tanaman tertentu (Fatiqin, 2015).

Berdasarkan hasil uraian diatas maka dilakukan penelitian isolasi dan karakterisasi mikroba pada tanah mangrove Rhizopora sp di kota Bontang. Penelitian ini dilakukan untuk menjawab masalah penelitian tentang teknik isolasi bakteri dari tanah mangrove serta karateristik bakteri yang berhasil diisolasi.

\section{METODE PENELITIAN}

\section{Alat dan Bahan}

Alat yang digunakan meliputi laminar air flow, inkubator, autoclave, erlenmeyer $100 \mathrm{ml}$ dan $250 \mathrm{~mL}$, tabung reaksi, cawan petri, ose lurus dan ose bulat, 
mikroskop, bunsen, object glass, cover glass, pinset, rak tabung reaksi, batang pengaduk, gelas kimia $50 \mathrm{~mL}$ dan hot plate. Bahan yang digunakan meliputi tanah mangrove, medium Nutrien Agar, Manitol, Milk Agar, Gelatin, Urea Agar, Lysine Iron Agar, Simmon Citrat Agar, Kliger Iron Agar, Flukonazol, alkohol, aquades, botol kaca steril, Iodin, Kristal Violet, Methylen Blue, Minyak Emersi, Safranin dan $\mathrm{NaCl} 0,9 \%$.

\section{Prosedur Kerja}

Isolasi bakteri dari tanah tumbuhan Rhizopora sp.

Sampel tanah dari mangrove Rhizopora sp. diambil pada kedalaman $\pm 20 \mathrm{~cm}$ dari atas permukaan secara aseptik dengan tujuan untuk mengurangi adanya kontaminasi bakteri dari udara dan permukaan tanah.

Teknik isolasi diawali dengan pembuatan seri pengenceran sampel. Sebanyak 1 gram sampel ditambahkan $9 \mathrm{~mL}$ aquades (pengenceran $10^{-1}$ ). Pengenceran dilakukan hingga tahap $10^{-5}$. Masing-masing pengenceran diambil \pm $1 \mathrm{~mL}$ dan dilakukan penanaman pada medium nutrient agar dengan metode streak plate. Medium disuplementasi dengan 2 ppm flukonazol dengan tujuan mencegah pertumbuhan fungi. Selanjutnya diinkubasi selama 2 hari pada suhu $37^{\circ} \mathrm{C}$. kemudian dilakukan pemurnian mikroba dengan menumbuhkan kembali bakteri yang telah tumbuh dari hasil isolasi sebelumnya untuk menghasilkan biakan isolatisolat bakteri yang murni. Selanjutnya dilakukan pengamatan karakteristik berdasarkan mikroskopis, makroskopis dan uji reaksi biokimia dari isolat-isolat murni tersebut.

\section{Karakterisasi Isolat Bakteri}

Pengamatan makroskopis dilakukan dengan mengamati bentuk dan warna dari sebuah koloni bakteri, dimana pengamatan terbagi menjadi tiga pengamatan yaitu dari atas untuk bentuk menyeluruh dan bentuk tepi koloni serta dari samping untuk tinggi koloni.

Pengamatan mikroskopis dilakukan dengan melakukan pewarnaan pada koloni bakteri. Terbagi menjadi dua yaitu pengecatan gram, pengecatan sederhana. Pengecatan ini dilakukan untuk menentukan golongan gram bakteri dan bentuk morfologi koloni bakteri. 
Uji reaksi biokimia dilakukan untuk melihat pertumbuhan bakteri pada medium khusus berdasarkan reaksi biokimia yang terjadi pada bakteri. Dilakukan 7 macam uji reaksi biokoimia yaitu uji reaksi fermentasi karbohidrat, uji urease, uji utilitas sitrat, uji pencairan gelatin, uji methyl red, uji hidrolisa polisakarida, protein dan lemak dan uji lysine dekarboksilasi.

\section{HASIL DAN PEMBAHASAN}

Berbagai macam mikoorganisme atau bakteri tumbuh dengan baik di tanah, kompleksnya nutrisi untuk pertumbuhan bakteri yang terkandung dalam tanah menyebabkan bakteri yang tumbuh sangat beragam. Isolasi bakteri dari penelitian ini diperoleh dari sampel tanah mangrove. Tanah mangrove yang diambil ialah tanah setelah air laut surut sehingga akan diperoleh sampel tanah yang tidak tidak terlalu cair. Sampel kemudian dibuat pengenceran bertingkat dari $10^{-1}$ hingga $10^{-5}$ dengan tujuan memperkecil atau mengurangi jumlah mikroba yang tersuspensi dalam cairan. Suspensi bakteri kemudian diinokulasi pada medium dengan teknik gores atau streak plate menggunakan ose bulat pada permukaan medium dengan pola tertentu dengan harapan sel-sel bakteri dapat membentuk koloni tunggal yang kemudian akan mempermudah pemurnian isolat bakteri. Medium yang digunakan ialah medium Nutrien Agar (NA) untuk mengisolasi bakteri secara umum. Kemudian bakteri yang telah diisolasi dimurnikan dengan menumbuhkan kembali isolat bakteri pada medium NA yang baru.
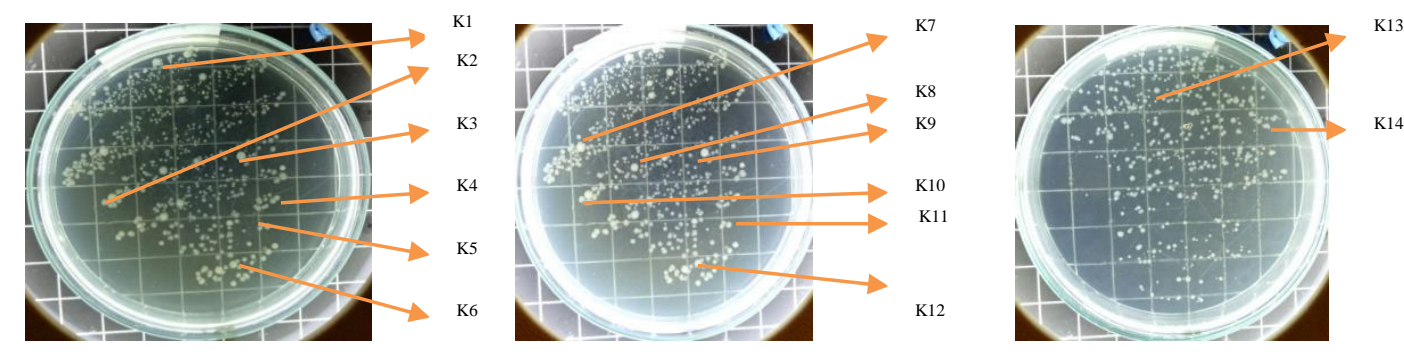

Gambar 1. Berbagai bentuk koloni isolat bakteri yang telah diisolasi dari tanah mangrove (ket : kode isolat K1-K14)

Selanjutnya isolat murni yang telah diperoleh dilakukan pengamatan morfologi secara makroskopis dan mikroskopis. Pengamatan secara makroskopis 
meliputi bentuk, bentuk tepi dan warna koloni. Bentuk koloni dan ukurannya sangat bervariasi seperti dapat dilihat pada Gambar 1.

Hidayat, (2006) mengatakan bahwa bentuk koloni dari suatu bakteri dipengaruhi oleh umur dan syarat pertumbuhan tertentu. Variasi bentuk bakteri yang terjadi juga dipengaruhi oleh faktor lingkungan, faktor makanan (medium tumbuh) dan suhu (minimum, optimum dan maksimum) (Ilyas,2001). Warna koloni yang tampak berbeda-beda menunjukkan adanya perbedaan pigmen. Menurut Savitri, (2006) bahwa pigmen yang terdapat pada bakteri diantaranya adalah pigmen karotenoid, antosianin, melanin, tripirilmethene dan phenazin. Masingmasing dari pigmen tersebut akan memberikan warna yang berbeda-beda. Warna merah dan kuning pada isolat disebabkan adanya karotenoid. Melanin memberikan warna coklat, hitam dan jingga. Tripilimethenes adalah pigmen yang dihasilkan oleh Serratia marcesness dan phenazin memberikan warna kuning. Jingga muda dan merah jingga (Savitri,2006). Ciri-ciri makroskopis isolat disajikan pada Tabel 1.

Tabel 1. Karakteristik morfologi bakteri tanah mangrove

\begin{tabular}{cccccc}
\hline \multirow{2}{*}{ No } & Kode & \multicolumn{4}{c}{ Ciri Pertumbuhan Koloni } \\
\cline { 3 - 6 } & Isolat & Tepi koloni & Ukuran koloni & Bentuk koloni & $\begin{array}{c}\text { Warna } \\
\text { koloni }\end{array}$ \\
\hline 1 & K1 & Lobate & Moserate & Irregular & Krem \\
2 & K2 & Serrate & Moserate & Irregular & Putih susu \\
3 & K3 & Undulate & Large & Irregular & Kuning \\
4 & K4 & Lobate & Moserate & Irregular & Putih susu \\
5 & K5 & Lobate & Small & Irregular & Krem \\
6 & K6 & Lobate & Moserate & Irregular & Kuning \\
7 & K7 & Serate & Large & Filamentous & Putih susu \\
8 & K8 & Serate & Large & Filamentous & Putih susu \\
9 & K9 & Filiform & Moserate & Filamentous & Krem \\
10 & K10 & Lobate & Moserate & Irregular & Putih susu \\
11 & K11 & Lobate & Moserate & Irregular & Putih susu \\
12 & K12 & Entire & Moserate & Circular & Krem \\
13 & K13 & Lobate & Small & Irregular & Kuning \\
14 & K14 & Entire & Small & Circular & Putih susu \\
\hline
\end{tabular}

Tabel 1 memperlihatkan bahwa sebanyak 9 isolat berbentuk tidak beraturan, 3 isolat berbentuk filamen dan 2 isolat berbentuk bulat. Sebanyak 7 isolat berwarna 
putih susu, 4 isolat berwarna krem dan 3 isolat berwarna kuning. Ukuran koloni isolat sebagian besar berukuran sedang dengan tepi koloni kebanyakan berbentuk berlekuk.

Pengamatan mikroskopis dilakukan dengan pengecatan gram dan pengecatan sederhana. Pewarnaan gram bertujuan untuk mengamati morfologi sel bakteri dan mengetahui kemurnian sel bakteri dimana bakteri terbagi menjadi dua jenis gram yakni gram positif dan gram negatif (Tabel 2).

Bakteri gram positif terlihat berwarna ungu karena asam-asam ribonukleat pada sitoplasma sel-sel gram positif membentuk ikatan yang lebih kuat dengan kompleks ungu kristal violet sehingga ikatan kimiawi tersebut tidak mudah dipecahkan oleh pemucat warna. Reaksi tersebut didasarkan atas perbedaan komposisi kimiawi dinding sel. Sel gram positif mempunyai dinding dengan lapisan peptidoglikan yang tebal dan bakteri gram negatif memiliki lapisan peptidoglikan yang lebih tipis dibanding bakteri gram positif (Sunatmo,2007). Bakteri gram negatif terlihat berwarna merah hingga merah muda. Bakteri gram negatif mengandung lipid dan lemak dalam presentase yang lebih tinggi daripada bakteri gram positif (Sudarsono,2008).

Jika dilihat dibawah mikroskop, bakteri gram positif akan berwarna ungu karena dapat menahan kompleks pewarna primer yaitu gram A (kristal violet) sampai akhir prosedur pewarnaan. Sedangkan bakteri gram negatif akan berwarna merah ketika diamati menggunakan mikroskop karena tidak dapat mempertahankan kompleks warna kristal violet dengan pembilasan cat gram C (alkohol aseton), lalu terwarnai oleh pewarna tandingan berupa cat gram D (safranin) yang akan terserap pada dinding selnya (Cappucino, 2001).

Hasil pengamatan mikroskopis ke-14 isolat terdapat 8 isolat berbentuk batang (Basil) dan bersifat gram negatif dan 1 isolat berbentuk spiral dan bersifat gram negatif. Sebanyak 3 isolat berbentuk batang (Basil) dan bersifat gram positif, 2 isolat berbentuk bulat rantai (Streptococcus) bersifat gram positif. Pada pewarnaan ini reagen yang digunakan ada 4 jenis yaitu gram A (kristal violet), gram B (iodine), gram C (alkohol aseton) dan gram D (safranin). 
Tabel 2. Karakterisasi isolat berdasarkan pengecatan gram

\begin{tabular}{cccc}
\hline & Kode & \multicolumn{2}{c}{ Karakterisasi Pengecatan Gram } \\
\cline { 3 - 4 } No & Isolat & Bentuk Koloni & Golongan Gram \\
\hline 1 & K1 & Basil & Negatif \\
2 & K2 & Basil & Negatif \\
3 & K3 & Spiral & Negatif \\
4 & K4 & Basil & Positif \\
5 & K5 & Streptococcus & Positif \\
6 & K6 & Basil & Positif \\
7 & K7 & Basil & Negatif \\
8 & K8 & Basil & Negatif \\
9 & K9 & Basil & Negatif \\
10 & K10 & Basil & Positif \\
11 & K11 & Basil & Negatif \\
12 & K12 & Basil & Negatif \\
13 & K13 & Basil & Positif \\
14 & K14 & Streptococcus
\end{tabular}

Karakterisasi dan klasifikasi sebagaian besar mikroba seperti bakteri digolongkan berdasarkan reaksi enzimatik maupun biokimia. Mikroba dapat tumbuh pada beberapa tipe metabolit tertentu yang dideteksi dengan interaksi mikroba dengan agen reagen test yang menghasilkan warna reagen. Reaksi-reaksi sel akan terjadi dengan melakukan pengujian-pengujian tertentu (Pelczar,1986). Isolat bakteri dapat diidentifikasi dengan beberapa uji reaksi bikoimia yaitu uji reaksi fermentasi karbohidrat, uji urease, uji utilitas sitrat, uji pencairan gelatin, uji methyl red, uji hidrolisa polisakarida, protein dan lemak dan uji Lysine Dekarboksilasi. Hasil uji biokimia disajikan pada Tabel 3.

Uji methyl red digunakan untuk menentukan adanya produk asam campuran dari fermentasi glukosa melalui jalur fermentasi berupa asam laktat, asam asetat, asam format dan asam suksinat (Cappucino, 2001). Hasil positif yang ditandai dengan terjadinya perubahan warna menjadi merah setelah methyl red dan reaksi negatif jika tidak terjadi perubahan warna.

Waluyo, (2004) menjelaskan bahwa jika medium berubah menjadi merah/merah muda menandakan bahwa bakteri ini menghasilkan asam-asam campuran sebagai hasil fermentasi yakni berupa metilen glikogen. Uji urease digunakan untuk melihat bakteri mampu menghasilkan enzim urease. Beberapa 
mikroorganisme mampu menghasilkan enzim urease yang menguraikan mikromolekul urea $\left.\left(\mathrm{NH}_{2}\right)_{2} \mathrm{CO}\right)$ menjadi karbondioksida $\left(\mathrm{CO}_{2}\right)$ dan amonia $\left(\mathrm{NH}_{3}\right)$. Urea menjadi amonium dan $\mathrm{CO}_{2}$ sehingga menyebabkan $\mathrm{pH}$ media menjadi basa dan akan terjadi perubahan media dari jingga menjadi merah.

Uji sitrat merupakan uji yang digunakan untuk melihat kemampuan mikroorganisme menggunakan sitrat sebagai sumber karbon (Duncan, 2005). Hasil positif ditunjukkan dengan adanya pertumbuhan bakteri dan terjadinya perubahan warna media dari hijau menjadi biru yang disebabkan oleh peningkatan $\mathrm{pH}$ media diatas 7,6. Uji pencairan gelatin dimana gelatin akan terurai oleh bakteri yang mensintesis enzim proteolisis. Larutan gelatin bersifat cair pada suhu ruang atau suhu kamar dan padat apabila berada dalam refrigrator. Apabila gelatin sudah terhidrolisis oleh mikroba maka akan tetap bersifat cair.

Uji fermentasi karbohidrat adalah uji untuk mengetahui bakteri memiliki kemampuan dalam memfermentasikan karbohidrat. Pada proses fermentasi karbohidrat akan diubah bakteri menjadi asam organik seperti asam laktat, asam format atau asam asetat. Dekarboksilasi lisin terjadi apabila bakteri dapat melakukan dekarboksilasi lisisn dan menghasilkan cadaverin yang bersifat basa sehingga adanya indikator BCP akan berwarna ungu.

Tabel 3. Karakterisasi isolat hasil uji reaksi biokimia

\begin{tabular}{ccccccc}
\hline \multirow{2}{*}{ Uji Reaksi Biokimia } & \multicolumn{7}{c}{ Kode Isolat } \\
\cline { 2 - 7 } & K1 & K2 & K3 & K4 & K5 & K6 \\
\hline Urease & + & + & + & - & + & + \\
Utilitas Sitrat & + & - & + & + & - & + \\
Fermentasi Karbohidrat & + & - & + & + & - & + \\
Lisin Dekarboksilase & + & + & - & + & + & - \\
MR (Methyl Red) & - & - & - & - & - & - \\
Pencairan Gelatin & - & - & - & - & - & - \\
Hidrolisa karbohidrat, & - & - & - & - & - & - \\
protein dan lemak & - & \multicolumn{7}{l}{ megatif / tidak ada perubahan }
\end{tabular}

Pada tabel 3 menunjukkan bahwa isolat $\mathrm{K} 1$, K3 dan K5 memiliki enzim urease, dapat memanfaatkan sitrat sebagai sumber karbon dan dapat 
memfermentasikan karbohidrat. Isolat K2 dan K5 memiliki enzim urease dan dapat melakukan dekarboksilasi lisin dan menghasilkan cadaverin. Sedangkan isolat K4 tidak memiliki enzim urease tetapi dapat menggunakan sitrat sebagai sumber karbon, melakukan fermentasi karbohidrat dan dekarboksilasi lisin. Hasil uji MR, gelatin dan hidrolisa karbohidrat, lemak dan protein ke-6 isolat menunjukkan hasil yang negatif.

Dari hasil karakterisasi secara mikroskopis, makroskopis dan uji reaksi biokimia yang diperoleh kemudian dibandingkan dengan ciri-ciri genus bakteri yang terdapat dalam tanah dan genus bakteri tanah yang memiliki potensi sebagai bakteri penghasil antibiotik. Golongan bakteri tanah penghasil antibiotik diantaranya seperti genus Bacilli, Pseudomonas, Lactobacilli, Enterebacteria, Micrococci, Miscellaneous bacteria dan Actinomycetes.

Berdasarkan hasil uji morfologi dan fisiologi isolat bakteri menunjukkan beberapa kelompok bakteri yang teridentifikasi berdasarkan karakter pada Holt, dkk (1994). Isolat K6 teridentifikasi sebagai bakteri gram positif berbentuk batang, dapat memfermentasikan karbohidrat, tidak dapat menghidrolisa pati namun beberapa spesiesnya mempunyai kemampuan hidrolisa pati.

Genus ini diduga ialah berasal dari keluarga kelompok Bacillus (Hot et.al, 1994). Beberapa isoalat lainnya termasuk bakteri gram negatif berbentuk batang, dapat menggunakan sitrat sebagai sumber karbon dan dapat memfermentasi karbohidrat diduga termasuk dalam keluarga kelompok Pseudomonas.

Hasil yang diperoleh hanya berdasarkan pengamatan makroskopis, mikroskopis dan uji reaksi biokimia sehingga masih diperlukan uji identifikasi yang lebih lanjut untuk mengetahui genus isolat yang lebih tepat.

\section{KESIMPULAN}

1. Hasil isolat bakteri yang diperoleh berbentuk batang, spiral dan bulat dengan warna putih susu, krem dan kuning dan sebagian besar bersifat gram negatif.

2. Hasil uji karakterisasi ke-14 isolat bakteri sifat fisiologis, morfologis dan uji reaksi biokimia tergolong genus Bacillus dan Psudomonas. 


\section{DAFTAR PUSTAKA}

Cappucino, James G., and Natalia, S. 2001. Microbiology : A Laboratory Manual, 6th Edition. Sinaeur Associates, Inc. Sunderland.

Duncan, F. 2005. MBC 1000L Applied Microbiology Laboratory Manual 4th Ed. New York: The McGraw-Hill Companies.

Fardiaz. S. 1993. Mikrobiologi Pangan 1. Gramedia. Jakarta.

Fatiqin, A. 2015. Eksplorasi Akrinomiset Sebagai Penghasil Antibiotika Dari Tanah Mangrove Sonneratia caseolaris DI Tanjung Api-Api. Jurnal Biota.1.1.

Hadioetomo, R. S. 1993. Teknik dan Prosedur Dasar Laboratorium Mikrobiologi. Gramedia. Jakarta.

Hidayat, N. 2006. Mikrobiologi Industri Edisi Pertama. ANDI. Yogyakarta

Holt, J., G, Krige, N.R., Sneath, P.H.A., Staley, J.T., and Williams, S.T. 1994. Bergey's Manual Of Determination Bacteriology $9^{\text {th }}$ Ed. Williams \& Wilkins, Maryland.

Ilyas, S. 2001. Mikrobiologi Dasar Diklat Kompilasi 28. USU Press. Medan.

Katili A.S. 2009. Struktur Vegetasi Mangrove di Kecamatan Kwandang Kabupaten Gorontalo Utara, Provinsi Gorontalo. Jurnal Pelangi Ilmu. 6. 2.

Pelczar, MJ., and Chan. 2005. Dasar-Dasar Mikrobiologi 2. UI Press. Jakarta

Savitri, S. D. N. 2006. Isolasi dan Karakterisasi Bakteri Halotoleran pada Peda Ikan Kembung (Rastrelliger sp.). Skiripsi Bogor. ITB.

Sudarsono, A. 2008. Isolasi dan Karakterisasi Bakteri pada Ikan Laut Dalam Spesies Ikan Gindara (Lepidocibium flavobronneum). Skripsi Bogor. ITB.

Sunatmo, T. 2007. Eksperimen Mikrobiologi Dalam Laboratorium. Andy Agency. Bogor.

Waluyo, L.2005. Mikrobiologi Umum. Universitas Muhammadiyah Press. Malang. 